\title{
Pesantren sebagai Benteng Ideologi Pancasila (Studi di Kabupaten Rejang Lebong dan Kabupaten Kepahiang)
}

\author{
Muhamad Arif Mustofa \\ Institut Agama Islam Negeri (IAIN) Curup, Indonesia \\ aripatmi@gmail.com \\ Mabrur Syah \\ Institut Agama Islam Negeri (IAIN) Curup, Indonesia
}

\begin{abstract}
Islamic boarding schools as educational institutions that have the principal principle of tafaaquh fi din have a tremendous influence on their santri. In addition, history also records from before the independent state of Indonesia, that pesantren became the frontline in expelling colonial colonizers and presenting peace in the archipelago even today. Even so, lately there have been a number of pesantren that have lost their way, they have stopped paying attention to the security and peace of the nation, they only think that in a pesantren it is a place to explore religious knowledge not others. Therefore, the purpose of this research is to explore the pesantren in fortifying the Pancasila. This study is a linear field with a descriptive qualitative approach, where data collected in the form of written or oral words from people who are the subject of research and observable behavior. Research data is sought through observation, interviews, and documentation. This research produces several things: first; the role of pesantren in rejang lebong and kepahiang districts is very good in terms of education, da'wah which is tasamuh, religious and moral services as well as ukhuwah islamiyah, except the second pesantren as Syafi'i imam; the efforts made by the pesantren in fortifying Pancasila, namely: the formation of friendly Islam with the TNI and the Police and the Commemoration of national and Islamic holidays, as well as social services. In contrast to the efforts made by the imam as Syafi'i pesantren which is to establish communication with the guardians of the santri who agree with them.
\end{abstract}

Keywords: Tradition; Adorn Sacrificial Animals; Kenagarian Bawan

\begin{abstract}
Abstrak
Pesantren sebagai lembaga pendidikan yang memiliki prinsip pokok tafaaquh fi din memberikan pengaruh yang luar biasa terhadap para santri-santrinya. Di samping itu, sejarah juga mencatat dari sebelum Negara Indonesia merdeka, bahwa pesantren menjadi garda terdepan dalam mengusir kolonial penjajah dan menghadirkan kedamaian di bumi nusantara bahkan sampai sekarang. Meskipun demikian, akhir-akhir ini ada beberapa pesantren yang kehilangan arah, mereka tidak lagi memperhatikan tentang keamanan dan ketentraman bangsa, mereka hanya berfikir kalau di pesantren adalah tempat mendalami ilmu agama saja tidak yang lain. Oleh karena itu, tujuan penelitian ini adalah menggali tentang pesantren dalam membentengi Pancasila.
\end{abstract}

FOKUS : Jurnal Kajian Keislaman dan Kemasyarakatan Vol. 4, No. 1, 2019

LPPM Institut Agama Islam Negeri (IAIN) Curup - Bengkulu

Available online: http://journal.staincurup.ac.id/index.php/JF

p-ISSN 2548-334X, e-ISSN 2548-3358 
Penelitian ini adalah field research dengan pendekatan kualitatif deskriptif, dimana data yang dikumpulkan berupa kata-kata tertulis atau lisan dari orang-orang yang menjadi subyek penelitian dan perilaku yang dapat diamati. Data penelitian dicari melalui observasi, wawancara, serta dokumentasi. Penelitian ini menghasilkan beberapa hal: pertama; peran pesantren di kabupaten Rejang Lebong dan Kepahiang sangat baik dalam hal pendidikan, dakwah yang tasamuh, pelayanan agama dan moral serta ukhuwah islamiyah, kecuali pesantren imam as Syafi'i kedua; usaha yang dilakukan pesantren dalam membentengi Pancasila yaitu: pembinaan islam yang ramah bersama TNI dan Polisi dan Peringatan hari besar nasional dan islam, serta bakti sosial. Berbeda dengan usaha yang dilakukan oleh pesantren imam as Syafi'i yakni menjalin komunikasi dengan wali santri yang sepaham dengan mereka.

Kata Kunci: Boarding School; Fort; Pancasila

\section{PENDAHULUAN}

Pesantren merupakan khazanah peradaban Nusantara yang telah ada sejak zaman Kapitayan, sebelum hadirnya agama-agama besar seperti Hindu, Budha, dan Islam. Pertemuan dengan agama besar tersebut pesantren mengalami perubahan bentuk dan isi sesuai dengan karakter masing-masing agama, tetapi misi dan risalahnya tidak pernah berubah, yaitu memberikan muatan nilai spiritual dan moral pada setiap prilaku masyarakat sehari-hari, baik dalam kegiatan sosial, ekonomi maupun kenegaraan. ${ }^{1}$

Sejak awal pesantren telah menjadi pusat pendidikan ${ }^{2}$ masyarakat mulai dari bidang agama, kanuragan (bela diri), kesenian, perekonomian dan ketatanegaraan. Karena itulah para calon pimpinan agama, para pujangga bahkan para pangeran calon raja dan sultan semuanya dididik dalam dunia pesantren atau padepokan. ${ }^{3}$

\footnotetext{
${ }^{1}$ Said Aqil Siraj, Islam Sumber Inspirasi Budaya Nusantara Menuju Masyarakat Mutamaddin; Urgensi Kajian Islam Nusantara, Jakarta: LTNU

${ }^{2}$.Pesantren merupakan salah satu jenis pendidikan Islam Indonesia yang bersifat tradisional untuk mendalami dan mengamalkan agama sebagai pedoman hidup keseharian atau disebut tafaquh fiddin dengan menekankan pentingnya moral dalam hidup bermasyarakat, pesantren telah hidup sejak 300-400 tahun yang lampau yang hampir menjangkau seluruh masyarakat muslim, dewasa ini pesantren diperkirakan menampung lebih dari lima juta santri.

${ }^{3}$ Mastuhu, Dinamika Sistem Pndidikan Pesantren, Jakarta: INIS, 1995, h. 3
} 
Sebagai lembaga pendidikan, pesantren meminjam istilah Husein Naser ialah "dunia tradisional Islam yakni dunia yang dikembangkan ulama dari masa ke masa" telah menjadi salah satu pilar kokoh kemerdekaan dan kemandirian negeri ini. ${ }^{4}$

Pada awal abad XX, ulama pesantren membentuk jaringan dan membangun rasa nasionalisme untuk melawan rezim kolonial. Tapi kontribusi besar pesantren dan jaringan ulama tidak banyak diakomodasi dalam narasi pengetahuan yang diciptakan oleh penguasa, terutama orde baru. Kontribusi besar pesantren sebagai lembaga pendidikan dan pergerakan kebangsaan di wilayah Nusantara inilah yang perlu kembali diaktualisasikan. Pesantren selalu tampil terdepan dengan para santrinya ketika Negara dalam ancaman, tidak diragukan lagi kegigihan para santri nusantra dalam melawan kolonial penjajah.

Di samping itu, dunia pesantren juga selalu menanamkan nilai-nilai cinta terhadap Negara dan selalu menjadi benteng terdepan dalam merawat Negara dan ideologinya. Seperti kita ketahui bersama Pancasila sebagai ideologi dan pandangan bangsa Indonesia tidak lepas dari rongrongan sekelompok orang yang ingin menggantinya, seperti ideologi liberal, komunis, dan khilafah. Mereka kurang memahami bahwa perumusan Pancasila bukan hanya hasil buah pikiran manusia melainkan juga merupakan anugerah dari Allah SWT. Ideologi Pancasila ada dalam segala lini kehidupan masyarakat dan bangsa serta sudah semestinya ideologi Pancasila ini diwujudkan dalam kehidupan masyarakat yang beragam baik suku, ras, agama, dan lain sebagainya di negeri ini. Sebagai Falsafah Negara tentu Pancasila sudah tentu memuat prisip dan kaedah negara yang penting serta istimewa bagi rakyat dalam hidup bernegara. ${ }^{5}$

Pesantren memiliki tugas yang tidak ringan. Pesantren harus berjuang lebih keras lagi untuk menjaga eksistensi negara ini supaya kedaulatannya tetap terjaga. Dari segi pendidikan, KH Muchtar Adam dalam satu

\footnotetext{
${ }^{4}$ Nurcholis Madjid, Bilik-Bilik Pesantren Sebuah Potret Perjalanan, (Jakarta: Paramidina, 1997)

${ }^{5}$ Sutrisno. "Peran Ideologi Pancasila Dalam Perkembangan Konstitusi Dan Sistem Hukum di Indonesia." JPK: Jurnal Pancasila \& Kewarganegaraan, 2016, h. 43
} 
kesempatan menyampaikan bahwa Pondok Pesantren secara historis adalah model pendidikan dan sistem pertama dan tertua di Indonesia. Pesantren sudah sejak lama menjadi lembaga yang membentuk watak dan peradaban bangsa serta mencerdaskan kehidupan bangsa yang berbasis pada keimanan, dan ketakwaan kepada Allah SWT serta akhlak mulia.

Pesantren sekarang mampu memerankan diri sebagai benteng pertahanan dari imperialisme budaya yang begitu kuat menghegemoni kehidupan masyarakat, khususnya di perkotaan. Perkembangan pesantren dengan sistem pendidikannya mampu menyejajarkan diri dengan pendidikan pada umumnya, sehingga tidak mungkin negara ini dipisahkan dari pesantren.

Demikian halnya juga pesantren yang ada di Bengkulu, seperti di kabupaten Rejang Lebong dan Kepahiang. Pesantren di dua kabupaten ini juga ingin selalu ikut berperan andil dalam aspek pendidikan maupun eksistensi negara. Pesantren Darussalam misalnya, selalu memberikan pendidikan yang tidak terbatas dengan pendidikan agama melainkan juga pendidikan karakter dan sikap dalam bermasyarakat dan bernegara, begitu juga dengan pesantren-pesantren yang lain seperti, ar Rahmah dan Miftahul Jannah. Akan tetapi akhir-akhir ini masyarakat cukup diresahkan dengan munculnya pesantren yang justru bukan mendukung terhadap ideologi negara, melainkan sebaliknya.

Sebagian pesantren di Bengkulu ada yang bersifat eksklusif, kegiatan yang dilakukan tidak lagi mencerminkan pesantren pada umumnya. Segala aktifitas yang berkaitan dengan perayaan hari-hari besar nasional maupun agama tidak ada, bahkan jauh dari kehidupan masyarakat yang ada di sekitarnya. Oleh sebab itu, penelitian ini mengangkat tentang "Pesantren Sebagai Benteng Ideologi Pancasila."

Penelitian ini bertujuan untuk mengetahui peran dan fungsi pesantren di kabupaten Rejang Lebong dan Kepahiang dalam membentengi Ideologi Pancasila dan usaha apa saja yang sudah dilakukan oleh pesantren di kabupaten Rejang Lebong dan Kepahiang agar tetap konsisten dalam menjaga idelogi Pancasila. 
Jenis penelitian yang peneliti lakukan guna mengungkapkan fakta tentang "peran pesantren dalam membentengi ideologi pancasaila" adalah penelitian field research, (penelitian lapangan) dengan pendekatan kualitatif deskriptif. ${ }^{6}$ Di samping itu, penelitian ini juga menggunakan satu pendekatan yaitu pendekatan kualitatif dan metode deskriptif. ${ }^{7}$

Adapun sumber data dalam penelitian terbagi menjadi dua: pertama; data primer (pesantren-pesantren yang ada di kab. Rejang Lebong dan Kab. Kepahiang), kedua; data skunder (pendukung) yang terdiri (literature baik berupa buku, artikel, maupun majalah) yang mendukung penelitian ini

Berkaitan dengan pengumpulan data dalam penelitian ini, peneliti menggunakan tiga teknik dalam mengumpulkan data, yaitu observasi, wawancara (nterview) tak terstruktur, dan dokumentasi. Wawancara ini dilakukan oleh peneliti terhadap pengasuh pesantren, santri, pegawai kemenag kabupaten khususnya yang berhubungan dengan pesantren, dan orang-orang yang berkaitan dengan kegiatan pesantren dalam rangka membentengi ideologi Pancasila. Adapun dalam analisis data, peneliti mendiskripsikan dan menguraikan tentang peran dan fungsi pesantren dalam membentengi ideologi Pancasila. Setelah data terkumpul, maka data tersebut dianalisis untuk mendapatkan konklusi. Hal iti dilakukan dengan menggunakan beberapa metode, yaitu reduksi data, penyajian data, dan Conclusion Drawing.

Peneliti juga melakukan pengecekan data sehingga data penelitian menjadi lebih valid, pengecekan itu dilakukan dengan perpanjangan kehadiran peneliti, ketekunan pengamatan, dan triangulasi (keabsahan data yang memanfaatkan sesuatu yang lain di luar data untuk keperluan pengecekan atau sebagai perbandingan terhadap data. ${ }^{8}$

\footnotetext{
${ }^{6}$ Akbar, Husaini Usman dan Purnomo Setiady. Metodologi Penelitian Sosial, (Jakarta: PT Bumi Aksara, 2003), h. 5

${ }^{7}$ Moh. Nazir, Metode Penelitian, (Bogor: Ghalia Indonesia, 2005), h. 89

${ }^{8}$ Sugiyono. Metode Penelitian Pendidikan (Pendekatan Kuantitatif, Kualitatif, dan $R \& D)$, (Bandung: Alfabeta, 2015), h. 373-374
} 
Penelitian ini menghasilkan pengetahuan dan pemahaman bahwa: peran pesantren yang ada di kabupaten Rejang Lebong dan Kepahiang sudah baik kecuali satu pesantren yakni imam Syafi'I, hal itu terlihat dari usaha-usaha yang sudah dilakukan pesantren dengan melakukan kegiatankegiatan yang melibatkan masyarakat dan aparat penegak hukum seperti diklat penguatan ideologi pancasila dan perlombaan di hari-hari besar islam dan hari besar nasional.

\section{PEMBAHASAN}

Kata peran memiliki makna yang luas, kata tersebut biasa disandarkan kepada person atau perorangan juga bisa disandarkan pada sebuah lembaga atau institusi. Peran didefinisikan sebagai karakterisasi yang disandang untuk dibawakan oleh seseorang dalam sebuah pertunjukan seperti drama, yang diartikan dalam konteks sosial sebagai fungsi yang dimiliki seseorang ketika menduduki jabatan atau posisi penting dalam struktur sosial. ${ }^{9}$

Teori peran ialah sebuah teori yang diterapkan dalam dunia sosiologi, psikologi dan antropologi yang mencakup perpaduan dari beberapa teori, orientasi maupun disiplin ilmu. Teori peran berbicara tentang istilah "peran" yang umum digunakan dalam dunia drama, dimana terdapat aktor dalam yang harus bermain sebagai tokoh tertentu dan dia dituntut berperan dan berperilaku dengan sikap-sikap tertentu. ${ }^{10}$

Adapun Soekanto lebih jauh menyebutkan bahwa dalam teori peranan (role theory) dikatakan peranan adalah sekumpulan sikap atau perilaku seseorang yang dikaitkan dengan suatu posisi tertentu. Peran yang berbeda dapat menjadikan perbedaan jenis tingkah laku. Akan tetapi, penyebab yang menjadikan tingkah laku itu sesuai atau tidak

${ }^{9}$ Edy Suhardono, Teori Peran (Konsep, Derivasi dan Implikasinya), (Jakarta: PT Gramedia, 1994), h. 3

${ }^{10}$ Sarwono, Sarlito Wirawan. Teori- Teori Psikologi Sosial, (Jakarta: Rajawali Pers, 2015), h. 215 
dengan situasinya relatif bebas, tergantung kepada seseorang atau sesuatu yang menjalankan peranan tersebut.

Dari beberapa ungkapan di atas, bisa dikatakan bahwa peranan adalah sesuatu yang diharapkan dimiliki oleh individu khususnya yang memiliki kedudukan di tengah-tengah masyarakat, dia dianggap berperan kalau masyrakat di sekelilingnya dapat mempercayainya.

Adapun fungsi adalah kata serapan Bahasa Inggris function, yang bermakna sesuatu yang mengandung kegunaan atau manfaat. Oleh karena itu, fungsi sebuah lembaga atau institusi formal adalah adanya kewenangan berbentuk hak dan tugas yang dimiliki oleh seseorang dalam posisi atau jabatannya pada sebuah organisasi untuk untuk mengerjakan sesuatu yang sesuai dengan bidangnya. Fungsi lembaga atau institusi. ${ }^{11}$

\section{Pancasila}

Sebagai ideologi dan falsafah hidup berbangsa dan bernegara, Pancasila menjadi sesuatu yang urgen untuk dipelajari setiap warga negara. Pengamalannya menjadi sebuah keharusan karena telah disepakati oleh pendiri bangsa ini. Sebaliknya, konsekuensi hukum bagi siapapun yang menginginkan perubahan ideologi negara ini harus ditegakkan.

Pancasila sebagai ideologi sudah disahkan menjadi dasar negara dan ideologi nasioanal, meskipun demikian, masih ada dua kelemahan krusial yang perlu dibenahi. Kelemahan itu terlihat dari aspek internal berupa konsistensi dan koheresinya ke dalam dan eksternal, yang berupa kemampuan untuk mewujudkan nila-nilai pancasila itu sendiri. ${ }^{12}$

Pancasila (lapisan budaya asli, Hindu, Budha, dan Islam) dapat merangkul semua kelompok (lapisan budaya asli, Hindu, Budha, dan Islam) dan memberikan ruang kepada semua golongan dengan segala keanekaragamannya, selain itu juga dapat mempersatukan identitasnya masing-masing. Tidak ada istilah untuk mendiskriminasikan dari suatu

${ }^{11}$ Muammar Himawan, Pokok-Pokok Organisasi Modern, (Jakarta: Bina Ilmu, 2004), h. 51

${ }^{12}$ Fatiyah. "Pemahaman Santri Mahasiswa Terhadap Nilai-Nilai Pancasila." Adabiyah, 2017, h. 47-48 
kelompok dengan kelompok lain, atau mayoritas dengan minoritas. Semua menurut Pancasila adalah sama tidak ada perbedaan. ${ }^{13}$

Secara etimologis, istilah Pancasila berasal dari kata Sansekerta dari India (bahasa kasta Brahmana) dan bahasa rakyat biasa adalah bahasa Prakerta. Muhammad Amin mengatakan, dalam bahasa Sansekerta "Pancasila" memiliki dua macam makna: ${ }^{14}$ 1) panca artinya lima dan syila (vokal i pendek) artinya batu sendi, azas atau dasar, jadi jika dirangkai menjadi dasar yang memiliki lima unsur; 2) panca artinya lima dan syiila (vokal i panjang) artinya peraturan tingkah laku, yang penting atau yang senonoh, jadi jika dirangkai menjadi lima aturan tingkah laku yang penting.

Dengan demikian, Pancasila bisa bermakna asas dasar sebagai acuan dalam hidup berbangsa, bernegara, dan bermasyarakat. Pancasila mengandung beberapa nilai luhur yang tercakup dalam sila-silanya. Nilai luhur tersebut yaitu:

Pertama, jika mengkaji makna dari sila "Ketuhanan Yang Maha Esa", sila ini menunjukkan bahwa apa yang berlaku di negeri ini, baik yang mengenai bangsa atau negara, masyarakat maupun perorangan harus sesuai dengan sifat-sifat Tuhan yang tak terbatas dan mulia. ${ }^{15}$ Sila pertama ini memiliki beberapa makna yaitu: percaya dan takwa kepada Tuhan Yang Maha Esa sesuai dengan agama dan kepercayaan masingmasing, hormat menghormati dan bekerjasama antara pemeluk agama dan penganut-penganut kepercayaan yang berbeda-beda, saling menghormati kebebasan menjalankan ibadah sesuai dengan agama dan kepercayaannya, dan tidak memaksa suatu agama dan kepercayaan kepada orang lain

\footnotetext{
${ }^{13}$ Bambang Ruseno Utomo. Hidup Bersama di Bumi Pancasila, Sebuah Tinjauan Tentang Hubungan Islam dan Kristen di Indonesia, (Malang : Pusat Studi Agama dan Kebudayaan , 1993), h. 27

${ }^{14}$ Noor Ms Bakry, Pendidikan Pancasila. Yogyakarta: Pustaka Belajar, 2010, h. 14

${ }^{15}$ Sunoto. Mengenal Filsafat Pancasila: Pendekatan melalui Metafisika, Logika, dan Etika, (Yogyakarta: Hanindita, 2003), h. 63
} 
Kedua, sila "Kemanusiaan Yang Adil dan Beradab" dapat diartikan bahwa dengan sila ini masyarakat di bangsa Indonesia ini seharusnya menjadi manusia yang berpegang pada nilai keadilan dan moral sehingga mewujudkan akhlak dan pribadi yang mulia. Nilai-nilai luhur yang ada dalam sila kedua yaitu: mengakui persamaan derajat, hak dan kewajiban antara sesama, saling tolong menolong dan tidak saling menyakiti, mengembangkan sikap tenggang rasa, menjunjung tinggi nilai kemanusiaan, berani membela kebenaran dan keadilan, serta gemar melakukan kegiatan kemanusiaan .

Ketiga, dari sila "Persatuan Indonesia"-masih menurut Noor Bakrymemuat beberapa nilai: menempatkan persatuan, kesatuan, kepentingan, dan keselamatan bangsa dan negara di atas kepentingan pribadi dan golongan, cinta tanah air dan bangsa, bangga sebagai bangsa Indonesia, rela berkorban untuk kepentingan bangsa dan Negara, dan memajukan pergaulan demi persatuan dan kesatuan bangsa yang ber-Bhineka Tunggal Ika.

Keempat, pada sila keempat ini menunjukkan bahwa musyawarah dalam segala persoalan harus dikedepankan sehingga terwujud rasa tentram di tengah-tengah masyarakat. Sila ini mengandung makna bahwa: tidak memaksakan kehendak, mengutamakan musyawarah dalam mengambil keputusan, mengutamakan kepentingan negara dan masyarakat, rasa tanggungjawab menerima dan melaksanakan hasil keputusan musyawarah, musyawarah untuk mencapai mufakat diliputi oleh semangat kekeluargaan, keputusan yang diambil harus dapat dipertanggung jawabkan secara moral kepada Tuhan Yang Maha Esa, menjunjung tinggi harkat dan martabat manusia serta nilai-nilai kebenaran dan keadilan.

Kelima, sila "Keadilan Sosial bagi Seluruh Rakyat Indonesia" bisa dimaknai bahwa setiap orang di seluruh lapisan bangsa ini harus mendapatkan keadilan yang merata baik dari segi hukum, ekonomi, dan lain sebagainya. Oleh karena itu sila ini bisa dimaknai dengan: bersikap adil, menjaga keseimbangan antara hak dan kewajiban, mengembangkan perbuatan-perbuatan yang luhur dengan suasana kekeluargaan dan 
gotong-royong, suka memberi pertolongan, menghormati hak orang lain, tidak boros, menjauhi sikap pemerasan, tidak melakukan perbuatan yang merugikan kepentingan umum, tidak bergaya hidup mewah, menghargai hasil karya orang lain, berusaha mewujudkan kemampuan yang merata dan berkeadilan sosial, dan suka bekerja keras.

Makna-makna sila di atas seharusnya menjadi pedoman dalam berbangsa. Tidak ada lagi perdebatan tentang ideologi negara lagi, pancasila sudah final. Pengamalan Pancasila sebagaimana maknanya di atas, tidak juga bertentangan dengan agama yang ada, semuanya memiliki tujuan yang baik bagi kemajuan dan ketentraman bangsa.

\section{Pesantren}

Jika melihat sejarahnya, awal perkembangan dan munculnya pesantren yaitu pada abad ke-19. Pesantren memiliki kiprah yang sangat besar di tengah-tengah masyarakat, banyak ulama lahir dari lembagalembaga pesantren sehingga menjadi corong dakwah di tempat tinggalnya. Selain itu, pesantren juga sangat gencar melakukan perlawanan terhadap kolonial belanda, baik yang terang-terangan maupun yang tidak, seperti halnya pemberontakan petani di Cilegon Banten pada tahun 1888, jihad aceh 1887 gerakan yang dipelopori oleh H. Ahmad Ripangi Kali Salak dan masih banyak lagi bukti yang lain yang menunjukan bahwa pesantren memiliki andil peran yang besar terhadap perjalanan Islam dan bangsa Indonesia. ${ }^{16}$

Pesantren memiliki ciri khas dalam proses belajar mengajar, siswa yang belajar di dalamnya disebut dengan istilah santri. Santri merupakan bagian mendasar kenapa satu lembaga disebut dengan pesantren. Sebagian mereka ada yang 24 jam tinggal di pesantren ada juga yang hanya beberapa jam saja tinggal di sana. Waktu yang lama ini lah menjadikan santri tahu dan belajar dari guru atau kiyainya baik belajar secara formal maupun belajar dari melihat dan memperhatikan kehidupan

\footnotetext{
${ }^{16}$ Sartono Kartodirjo, Religious Movement of Java in The 19th and 20th Centuries,. (Yogyakarta, 1970), h. 15
} 
kiyainya. Oleh karena itu, karakter para santri akan terbentuk sebagaimana karakter kiyai sebagai figure (uswah) yang diteladaninya.

Pesantren bisa dimaknai sebagai lembaga pendidikan tradisional yang menyiapkan asrama sebagai tempat menginap santri dan dididik oleh kiyai. Para santri berada di dalam komplek yang mencakup tempat ibadah dan ruang belajar untuk mempelajari ilmu agama. Komplek ini umumnya dikelilingi oleh pagar untuk memudahkan dalam memantau para santri. ${ }^{17}$

Kiprah dan manfaat pesantren secara umum begitu dirasakan oleh masyarakat. Salah satu yang menjadi contoh utama adalah, pembentukan dan terbentuknya kader-kader ulama dan pengembangan keilmuan Islam, selain itu, pesantren juga merupakan gerakan-gerakan protes terhadap pemerintah kolonial Hindia Belanda. Di mana gerakan protes tersebut selalu dimotori dari dan oleh para penghuni pesantren. Setidaknya dapat disebutkannya misalnya; pemberontakan petani di Cilegon-Banten 1888. Dengan demikian, maka pesantren bisa didefinisikan dengan lembaga pendidikan yang memiliki santri-santri yang belajar dan tinggal selama 24 jam penuh di dalam pesantren, santri-santri tersebut memiliki ketaatan yang tinggi terhadap para kiainya, melebihi siswa kepada gurunya di tempat lain.

Berkaitan dengan peran dan fungsi pesantren, ada baiknya kita memperhatikan apa yang disampaikan oleh KH. M. Yusuf Hasyim, beliau menyampaikan: di samping mencetak para pendakwah yang menekankan amar ma'ruf dan nahi munkar, pesantren sendiri juga bisa disebut pendakwah, bahkan telah melekat dalam pemahaman masyarakat bahwa pesantren berperan dengan dakwah bil halnya. Lebih jauh lagi, tulisan A. Khudori Soleh yang bertema "Mengembalikan Pesantren NU Sebagai Agent of Change", menjelaskan bahwa pesantren harus memformulasikan dirinya sebagai lembaga pendidikan yang mampu menjawab tuntutan masa depan tanpa kehilangan jati dirinya. Oleh karena itu sebagai lembaga pendidikan pesantren tadak hanya dituntut mampu mendidik masyarakat tentang ajran agamanya,

\footnotetext{
${ }^{17}$ Prastiwi, Merlia Indah. "Politisi Pesantren dan Pergeseran Fungsi Pesantren di Madura." KARSA: Jurnal Sosial \& Budaya Keislaman, 2015, h. 209
} 
terlebih lagi pesantren harus mampu tampil sebagai pelopor perubahan (Agent of change). Jadi, pesantren harus mampu menjawab dan mampu memberikan pemikiran-pemikiran baru dan tindakan-tindakan alternatif dalam pelbagai persoalan keagamaan dan kemasyarakatan. ${ }^{18}$

Secara mendasar, Halim menyebutkan bahwa peranan Pondok Pesantren yang lebih fungsional dan berpotensi antara lain sebagai berikut: ${ }^{19}$

\section{a) Pusat Kajian Islam (Pendidikan)}

Sebagaimana kita ketahui, pada dasarnya pendidikan yang ada di pesantren lebih mengutamakn pada bidang agama;

b) Pusat Pengembangan Dakwah (Tasamuh)

Dawah merupakan bagian kewajiban setiap muslim. Dakwah memiliki makna untuk mengajak kepada keimanan dan ketakwaan kepada Allah. Hal ini juga bisa dilakukan dengan memberikan contoh yang baik atau dalam bahasa agama disebut uswatun hasanah;

c) Pusat Pelayanan Agama dan Moral

Pesantren juga memiliki tujuan mulia yaitu memberikan pelayanan agama dan moral. Akhlak yang terjaga dengan baik akan menimbulkan ketenteraman di tengah-tengah masyarakat;

d) Pusat Solidaritas dan Ukhuwah Islamiyah (Sosial)

Pesantren senantiasa mengutamakan kearifan dan kebijaksanaan dalam mengajak (hikmah), pesantren paham betul bahwa seseorang tidak bisa dipaksa untuk melakukan syariat agama tanpa kemauannya sendiri secara ikhlas. Selain itu, tutur kata yang baik (mauidhah hasanah) senantiasa digunakan oleh pesantren dalam berdakwah, kalaupun terjadi perdebatan dan adu argumentasi pesantren tetap dengan cara (al ahsan) sebagai ciri khasnya.

${ }^{18}$ Muhamad In'am Esha, NU di Tengah Globalisasi; Kritik, Solusi dan Aksi. Malang: UIN Maliki Press, n.d, h. 125

${ }^{19}$ A. Halim, Manajemen Pesantren, (Yogyakarta: Pelangi Aksara, 2005), h. 2005 


\section{PEMBAHASAN}

\section{PESANTREN DARUSSALAM}

Berdasarkan hasil wawancara dan observasi yang peneliti lakukan, Pesantren Miftahul Jannah memiliki peran dalam menjaga ideologi Pancasila melalui beberapa hal:

\section{Pusat Kajian Islam (Pendidikan)}

Pesantren Darussalam sebagai pesantren yang memiliki jargon "Hubbul Waton Minal Iman" memiliki visi meningkatkan pembinaan yang efektif bagi calon pemimpin masa depan yang kreatif dan inovatif menguasai ilmu pengetahuan dan teknologi dengan landasan iman dan taqwa serta akhlakul karimah.

Kegiatan yang dilakukan di pesantren Darusalam, diawali dengan qiyamul lail, dilanjutkan solat subuh berjamaah, kemudian menghafal kosa kata bahasa Arab dan Inggris, sarapan pagi, upacara bendera tiap hari senin, belajar secara klasikal, shalat Zuhur berjamaah, istirahat dan makan siang, shalat Ashar berjamaah, olah raga, shalat Maghrib, dilanjutkan dengan tadarus Al-Qur'an, murojaah, belajar kutubul mu'tabaroh, dan shalat Isya' berjamaah, khitobah, dan pada hari-hari tertentu juga dilaksanakan peringatan maulid nabi, isra' mikraj, Peringatan tahun baru Islam dan Peringatan hari santri.

Pada momen tertentu sebagaimana misi pesantren menumbuhkan penghayatan terhadap falsafah negara Pancasila, pesantren Darussalam juga mengundang pihak TNI dan Polri, untuk memberikan pembekalan kepada para santri agar mencintai negaranya. Dengan demikian pesantren Darusalam telah memiliki andil dalam membentengi ideologi Pancasila. Hal ini sesuai dengan sila ke 4, di mana masyarakat ikut menghormati seluruh pihak aparatur Negara seperti TNI dan polisi. Semuanya bekerja sama dalam menjaga kedaulatan dan ketentraman Negara.

\section{Pusat Pengembangan Dakwah (Tasamuh)}

Dakwah yang di lakukan oleh kiyai dan para ustadz pesantren Darusalam dilakukan di dalam pesantren dan luar pesantren, kegiatan dakwah yang didalam pesantren peringatan maulid nabi, isra' mikraj, peringatan tahun baru Islam dan peringatan hari santri dengan 
mengundang masyarakat luas ke pesantren. Sedangkan dakwah yang dilakukan di luar pesantren Darusalam yang dilakukan oleh kiyai dan para ustadz adalah dengan mengisi khutbah di masjid-masjid di sekitar pesantren, ceramah takziah, walimatul 'urs, dan peringatan hari-hari besar Islam, semua kegiatan dakwah tersebut dilakukan dengan mempraktikkan dakwah yang tasamuh (toleran). Oleh sebab itu, pesantren Darussalam telah ikut berperan dalam membentengi ideologi negara Indonesia melalui dakwahnya yang tasamuh bukan yang keras dan meresahkan.

\section{Pelayanan Agama dan Moral}

Pesantren Darusalam sebagai tempat tafaquh fidin selalu mengedepankan pentingnya akhlak dan etika, karena posisi akhlak lebih tinggi dari ilmu. Hal ini dapat dilihat dari salah satu misi pesantren Darussalam yaitu Meningkatkan pembinaan yang efektif bagi calon pemimpin masa depan yang kreatif dan inovatif menguasai ilmu pengetahuan dan teknologi dengan landasan iman dan taqwa serta akhlakul karimah. Jadi salah satu hasil yang dikehendaki bagi para santri yang belajar di pesantren Darusalam adalah santri-santri yang kreatif dan inovatif, sehingga mampu menjawab tantangan zaman, menguasai ilmu pengetahuan dan teknologi, sehingga mampu menjadi obor di tengahtengah masyarakat dengan mengedepankan akhlak dan budi pekerti. Karakter seorang santri sebaiknya pinter lagi bener, ahli zikir dan juga fikir.

Oleh sebab itu, bisa dikatakan bahwa tujuan pesantren Darussalam Kepahiang memilik tujuan yang sama dengan ideologi Pancasila yakni mewujudkan manusia yang beradab dan beretika, sehingga ketika mereka terjun di tengah-tengah masyarakat mereka akan bisa menghadirkan kerukunan dalam perbedaan dan keberagaman.

\section{Pusat Solidaritas dan Ukhuwah Islamiyah (Sosial)}

Pesantren menjalin hubungan yang harmoni dengan masyarakat sekitar pesantren, sehingga keberadaan pesantren betul-betul dirasakan manfaatnya bagi masyarakat di sekitar pesantren.

Keadaan ini semakin hari semakin membuat masyarakat mengupayakan untuk mengantisipasi dengan mencari tempat yang tepat 
untuk sebagai benteng bagi mereka setelah terjun di tengah-tengah masyarakat nantinya. Tempat yang dimaksud itu adalah Pondok Pesantren. Lebih dari semua itu Pondok Pesantren adalah sebagai wadah dari menciptakan Ulama' yang mumpuni.

Dengan Manhaj Ahlusunnah Wal-Jamaah, maka pesantren Darussalam Kepahiang selalu menjunjung tinggi ukhuwah Islamiyah, Ukuwah Basariyah, Ukhuwah dan Ukhuwah Watoniah. Nilai-nilai ini sudah barang tentu sejalan dengan Pancasila yaitu Persatuan Indonesia dan keadilan sosial.

\section{PESANTREN AL MUNAWARAH \\ Pusat Kajian Islam (Pendidikan)}

Pesantren Al-Munawaroh Kepahiang adalah pesantren yang menganut model Salafiyah dan mengkombinasikannya dengan kurikulum Kementerian Agama, Pendidikan yang diselenggarakan oleh Pesantren Almunawaoh Kepahiang terdiri dari dua program yaitu Pendidikan Salafiah dan Pendidikan Formal.

Kegiatan yang menjadi rutinan di pesantren ini adalah pembacaan ratib al-hadad dan Istighosah, yang selalu dibaca di pesantren ini, dan kegiatan serupa dengan mengundang jumlah masa yang besar dilakukan saat malam 1 Muharam. Disamping kegiatan-kegiatan tersebut, di pesantren ini juga dilakukan pelatihan kaligrafi, pelatihan hadrah, kitobah dan selalu dilakukan peringatan hari Santri. Upacara bendera dan juga pertemuan-pertemuan untuk meperkuat rasa nasionalisme yang melibatkan, Bupati Kepahiang, Kesbangpol, DPRD, polisi dan TNI juga selalu dilaksanakan. Oleh karena itu, pesantren Al-Munawaroh memiliki andil yang baik dalam membentengi ideologi negara Pancasila.

\section{Pusat Pengembangan Dakwah (Tasamuh)}

Pada peringatan hari-hari besar agama, pesantren mengadakan lomba-lomba yang diikuti oleh para santri, seperti lomba hafalan surat pendek, azan dan iqomat, hafalan bacaan shalat, dan shalawat. Acara puncaknya yakni dengan mengadakan pengajian yang dihadiri oleh masyarakat umum. Adapun pada hari-hari besar nasional, pesantren 
mengadakan upacara sebagai bentuk penghormatan kepada lambang Negara, seminar yang bertajuk penguatan cinta tanah air, diklat DTD banser yang diisi oleh anggota polisi maupun TNI. Di samping itu, pesantren juga mengadakan perlombaaan yang diikuti oleh masayarakat umum, Oleh sebab itu, pesantren ini ikut berperan dalam membentengi ideologi negara melalui dakwahnya yang menyejukan bukan membingungkan dan meresahkan.

\section{Pelayanan Agama dan Moral}

Pesantren al Munawaroh senantiasa memberikan pelayanan agama dan moral baik kepada santri maupun kepada masyarakat luas. Satu di antara nilai yang diterapkan oleh pesantren al Munawaroh adalah nilainilai kesederhanaan dan kemandirian. Oleh karena itu, pesantren al Munawaroh tidak saja menjadi pusat tafaquh fi din tetapi juga membekali para santri dengan nilai-nilai kewirausahaan.

Oleh karena itu, usaha yang dilakukan pesantren ini sejalan dengan nilai-nilai yang terkandung dalam Pancasila, sehingga bisa dikatakan pesantren al Munawaroh ikut andil dalam mengamalkan dan membentengi ideologi negara.

\section{Pusat Solidaritas dan Ukhuwah Islamiyah (Sosial)}

Pesantren al Munawaroh Kabupaten Kepahiang yang menjadi karakter khas Islam moderat. Adapun kegiatan yang sering dilakukan pondok ini bersama ormas yang ada seperti PCNU, GP Ansor, maupun Muslimat melakukan sunatan masal, santunan anak yatim dan dhuafa', sosialisasi tentang vaksin, Keluarga Berencana (KB), dan lain-lain. Dengan demikian, pesantren ini selalu mengedepankan nilai kebersamaan dan kebermanfaatan dalam setiap kegiatan yang dilakukan serta menjadi bukti bahwa pesantren ini mengamalkan nilai-nilai Pancasila.

\section{PESANTREN MIFTAHUL JANNAH}

\section{Pusat Kajian Islam (Pendidikan)}

Pesantren Miftahul Jannah sebagai pesantren yang memiliki prinsip moderat menjadikan dirinya sebagai pusat kajian Islam maupun pendidikan dari mulai tingkat dasar sampai aliyah. Pendidikan yang 
dilakukan oleh pesantren tersebut mengikuti kurikulum yang ditetapkan pemerintah. Meskipun demikian, pesantren tersebut tetap menjaga karakteristik pesantren dengan tetap memberikan nilai lebih melalui pendalaman ilmu agama, baik dari ilmu kaidah bahasa Arab, fiqih, maupun akidah.

Kegiatan yang dilakukan sama persis dengan kegiatan pada lembagalembaga pendidikan yang lain. Upacara tetap dilakukan di sana bahkan tidak jarang pertemuan-pertemuan untuk meperkuat rasa nasionalisme yang melibatkan polisi juga dilaksanakan di sana. Oleh karena itu, dalam pendidikan pesantren Miftahul Jannah memiliki andil dalam membentengi ideologi Pancasila.

\section{Pusat Pengembangan Dakwah (Tasamuh)}

Pesantren Miftahul Jannah berusaha untuk selalu mengembangkan dakwahnya melalui berbagai hal, mulai dari peringatan-peringatan hari besar Islam bahkan hari-hari besar nasional. Pengembangan dakwah ini dilakukan dengan cara yang sederhana (mudah diterima) dan berbaur dengan masyarakat di sekitarnya. Pada peringatan hari-hari besar agama, pesantren mengadakan lomba-lomba yang diikuti oleh para santri, seperti lomba hafalan surat pendek, azan dan iqomat, hafalan bacaan shalat, dan shalawat. Oleh sebab itu, pesantren ini ikut berperan dalam membentengi ideologi negara melalui dakwahnya yang menyejukan bukan membingungkan dan meresahkan.

\section{Pelayanan Agama dan Moral}

Dari wawancara peneliti dengan pimpinan pesantren, beliau mengatakan bahwa pendidikan moral yang diajarkan di pesantren Miftahul Jannah dengan cara memberikan contoh nyata secara langsung terhadap para santri-santrinya. Beliau mengatakan, sebagai seorang yang dijadikan paling depan, sangat berhati-hati dalam bertutur kata dan berperilaku di hadapan para santrinya. Di samping itu, para santri juga diajarkan beberapa kitab yang secara spesifik membahas tentang moral, seperti kitab ta'lim muta'alim, dan alala.

Oleh sebab itu, bisa dikatakan bahwa pesantren ini memilik tujuan yang sama dengan ideologi Pancasila yakni mewujudkan manusia yang 
beradab dan beretika, sehingga ketika mereka terjun di lapangan atau masyarakat mereka akan bisa menghadirkan kerukunan dalam perbedaan dan keberagaman.

\section{Pusat Solidaritas dan Ukhuwah Islamiyah (Sosial)}

Berkaitan dengan solidaritas dan bakti sosial, pesantren Miftahul Jannah mengadakan pengobatan gratis bagi masyarakat umum. Selain itu, pesantren ini juga memberikan sosialisasi keluarga berencana, dan tidak jarang pesantren ini mengadakan pengajian umum yang diikuti oleh masyarakat sekitar dan tokoh masyarakat di Kabupaten Rejang Lebong. Dengan adanya acara tersebut, umat Islam bisa saling bertemu dan saling bersilaturahmi. Hubungan baik yang dibangun oleh pesantren inilah, yang mencerminkan sosial yang baik sehingga tidak berseberangan dengan semangat Pancasila.

\section{PESANTREN IMAM SYAFI'I}

\section{Pusat Kajian Islam (Pendidikan)}

Berkaitan dengan peran pesantren Imam Syafi' I sebagai pusat kajian Islam, pesantren ini fokus terhadap tahfid al Quran. Pihak pesantren berupaya untuk mencetak para generasi yang hafal al Quran. Meskipun demikian, sangat disayangkan pesantren ini kurang memperhatikan pendidikan formal. Seluruh anak yang mukim di pesantren tidak mendapat pendidikan formal sebagaimana anak yang sekolah di tempat lain. Banyak dari anak-anak yang mengambil paket $\mathrm{C}$ demi untuk mendapatkan legalitas ijazah.

Dalam proses pendidikan, tidak diajarkan juga bagaimana seharusnya warga negara mencintai negaranya. Para santri tidak diperkenalkan dengan upacara, hari-hari nasional, bahkan hari santri juga. Oleh sebab itu peran pesantren ini sebagai pusat dakwah lebih cenderung eksklusif.

Pengajian rutin yang dilakukan pada setiap minggunya juga cenderung tertutup. Jamaah pengajian lebih dominan dari wali santri saja bukan masyarakat sekitarnya.

Dari data yang diperoleh, pesantren ini juga pasif untuk mentaati aturan sebagai lembaga pendidikan pesantren. Progress dari pesantren 
mulai dari siswa dan kegiatan yang dilakukan tidak dilaporkan kepada Ka. Kemenag Kab. Rejang Lebong bagian pesantren. Dengan demikian, pesantren Imam As Syafi' I sebagai pusat pendidikan atau kajian Islam sudah diterapkan melalui pengajian rutin dan tahfid al Quran, akan tetapi perannya sebagai warga Negara yang hidup di Indonesia dan patuh kepada aturan kurang diperhatikan. Tidak terlihat usaha pesantren dalam menjaga dan membentengi ideologi Pancasila sebagai falsafah berbangsa.

\section{Pusat Pengembangan Dakwah (Tasamuh)}

Berdasarkan dengan wawancara yang dilakukan oleh peneliti kepada pengasuh pesantren dan beberapa santri, mereka mengatakan bahwa pesantren Imam as Syafi'I, biasanya menggelar pengajian sebagai media dakwah hanya dihadiri oleh kalangan mereka sendiri. Kegiatan tahfid yang dilaksanakan di dalam pesantren tidak boleh ditonjolkan dalam event-event perlombaan. Para santri mengaku bahwa perlombaan seperti halnya MTQ tidak pernah diikuti, hal itu disebabkan larangan pengasuh pesantren. Sebuah peristiwa yang ironis kalau prestasi dan kemampuan yang mereka miliki tidak boleh dijadikan sebagai media dakwah dan berlomba-lomba dalam kebaikan.

Oleh sebab itu, pengembangan dakwah yang dilakukan kurang bisa dirasakan oleh banyak orang sehingga peran pesantren yang seharusnya sesuai dengan nilai-nilai Pancasila dengan toleransinya tidak diamalkan.

\section{Pelayanan Agama dan Moral}

Pesantren Imam Asyafi'I memberikan pemahaman agama melakukan program tahfidnya. Di samping itu, ada juga materi lain yang diajarkan di sana, seperti fiqih dan nahwu meskipun hanya dengan waktu yang sedikit. Jika hal ini dilihat dari nilai-nilai dalam Pancasila, kita akan menemukan bahwa pesantren ini secara tidak langsung ikut berperan dalam mengamalkannya yaitu: Ketuhanan Yang Maha Esa. Mereka mengenalkan bagaimana kewajiban seorang muslim itu harus dilakukan.

Berkaitan dengan tugas pesantren dalam membentuk moral, pesantren Imam As Syafi'i kurang memperhatikan hal tersebut. Berdasarkan wawancara peneliti dengan para santri, tidak pernah ada kegiatan yang dilakukan pesantren dengan melibatkan masyarakat 
sekitarnya, bahkan ada santri yang sudah keluar dari pesantren tersebut, hubungannya menjadi renggang dengan keluarganya. Ia tidak diajarkan untuk menerima perbedaan dan menganggap apa yang tidak sesuai dengan mereka menjadi keliru. Hal ini tentu tidak sesuai dengan pesan yang terkandung dalam Pancasila, di mana beradab menjadi salah satu yang harus dilaksanakan sehingga hubungan dengan keluarga, saudara, kerabat, bahkan sebangsa bisa terjalin dengan baik.

\section{Pusat Solidaritas dan Ukhuwah Islamiyah (Sosial)}

Pesantren sebagai pusat persatuan dan persaudaraan khususnya umat Islam harus terus berjuang sesuai dengan koridornya. Tidak semestinya pesantren menjadi sumber terkotak-kotaknya umat hanya karena beda masalah furu'. Di samping itu, pesantren juga harus menciptakan para lulusan yang peka terhadap permasalahan masyarakat, solidaritas yang tinggi diwujudkan melalui sikap tolong menolong harus direalisasikan. Berkaitan dengan hal tersebut, pesantren Imam as Syafi'i kurang memiliki peran dalam mewujudkannya. Ia membangun hubungan yang harmonis hanya dengan yang sepaham. Hal ini terlihat ketika peneliti menemukan bahwa data pesantren tidak pernah dilaporkan. Bahkan menurut Kasi. Pend. Diniyah dan Pondok Pesantren pihak pesantren Imam as as Syafi'I pernah berkunjung dengan mengajak aparat seakanakan ingin menunjukan powernya. Oleh karena solidaritas dan ukhuwah islamiyah sebagai tugas pesantren belum dapat diwujudkannya padahal persatuan dan gotong royong ini juga merupakan bagian dari butir Pancasila. Berdasarkan hal tersebut maka, pesantren Imam Syafi'I tidak berperan dalam membentengi ideologi Pancasila melalui solidariatas dan persaudaraan.

Untuk lebih mudah dalam melihat peran dan fungsi pesantren dalam membentengi ideologi Pancasila serta usaha-usaha yang sudah mereka lakukan, dapat dilihat dari tabel berikut: 
Tabel 1

Peran \& Usaha Pesantren dalam Membentengi Ideologi Pancasila

\begin{tabular}{|c|c|c|c|c|}
\hline No & $\begin{array}{c}\text { Nama } \\
\text { Pesantren }\end{array}$ & $\begin{array}{c}\text { Peran dan } \\
\text { Fungsi }\end{array}$ & $\begin{array}{l}\text { Usaha yang } \\
\text { dilakukan }\end{array}$ & Sila Pancasila \\
\hline \multirow{4}{*}{1} & \multirow{4}{*}{$\begin{array}{l}\text { Pesantren } \\
\text { Darussalam } \\
\text { Kepahiang }\end{array}$} & $\begin{array}{l}\text { Pusat Kajian } \\
\text { Islam } \\
\text { (Pendidikan) }\end{array}$ & $\begin{array}{lr}\text { Pembekalan } & \text { para } \\
\text { santri } & \text { dengan } \\
\text { melibatkan } & \text { TNI } \\
\text { dan Polri dalam } \\
\text { menguatkan cinta } \\
\text { dan bela Negara }\end{array}$ & $\begin{array}{l}\text { Butir sila-4, } \\
\text { mengutamakan } \\
\text { kepentingan umum } \\
\text { (Negara dan masyarakat di } \\
\text { atas kepentingan pribadi) } \\
\text { Sila-3 bangga sebagai } \\
\text { warga Negara Indonesia }\end{array}$ \\
\hline & & $\begin{array}{l}\text { Pusat } \\
\text { Pengembangan } \\
\text { dakwah } \\
\text { (tasamuh) }\end{array}$ & $\begin{array}{l}\text { Peringatan hari-hari } \\
\text { besar dan nasional } \\
\text { dengan dakwah } \\
\text { yang melibatkan } \\
\text { seluruh santri dan } \\
\text { masyarakat umum } \\
\text { di luar pesantren }\end{array}$ & $\begin{array}{l}\text { Butir sila-5, } \\
\text { mengembangkan } \\
\text { perbuatan-perbuatan yang } \\
\text { luhur mencerminkan sikap } \\
\text { kekeluargaan dan gotong } \\
\text { royong }\end{array}$ \\
\hline & & $\begin{array}{l}\text { Pelayanan } \\
\text { agama dan } \\
\text { moral }\end{array}$ & $\begin{array}{l}\text { Pembentukan } \\
\text { karakter sebagai } \\
\text { tujuan utama } \\
\text { pesantren meliebihi } \\
\text { ilmu pengetahuan } \\
\text { (pembentukan } \\
\text { akhlak mulia) }\end{array}$ & $\begin{array}{l}\text { Butir sila-2, kemanusiaan } \\
\text { yang adil dan beradab. } \\
\text { Adab yang diwujudkan } \\
\text { dalam kehidupan } \\
\text { bermasyarakat untuk } \\
\text { saling menghargai dan } \\
\text { menghormati }\end{array}$ \\
\hline & & $\begin{array}{l}\text { Pusat } \\
\text { solidaritas dan } \\
\text { ukhuwah } \\
\text { Isalamiyah } \\
\text { (sosial) }\end{array}$ & $\begin{array}{lr}\text { Kerjasama yang } \\
\text { dijalin dengan baik } \\
\text { oleh pesantren dan } \\
\text { masyarakat } \\
\text { sekitarnya. }\end{array}$ & $\begin{array}{l}\text { Butir sila-3, memajukan } \\
\text { pergaulan demi persatuan } \\
\text { dan kesatuan bangsa }\end{array}$ \\
\hline \multirow[t]{2}{*}{2} & \multirow[t]{2}{*}{$\begin{array}{l}\text { Pesantren al } \\
\text { Munawaroh } \\
\text { Kepahiang }\end{array}$} & $\begin{array}{l}\text { Pusat Kajian } \\
\text { Islam } \\
\text { (Pendidikan) }\end{array}$ & \begin{tabular}{lr}
\multicolumn{2}{l}{ Penyelenggaraan } \\
pendidikan yang \\
seimbang antara \\
pendidikan agama \\
dan umum. \\
Pertemuan antara \\
pejabat daerah dan \\
masyarakat yang \\
diinisiasi \\
pesantren
\end{tabular} & $\begin{array}{l}\text { Butir sila-2, mengakui } \\
\text { persamaan hak dan } \\
\text { kewajiban antar manusia }\end{array}$ \\
\hline & & $\begin{array}{l}\text { Pusat } \\
\text { Pengembangan } \\
\text { dakwah } \\
\text { (tasamuh) }\end{array}$ & $\begin{array}{l}\text { Perlombaan pada } \\
\text { hari-hari besar } \\
\text { nasional dan islam }\end{array}$ & $\begin{array}{l}\text { Butir sila-5, } \\
\text { mengembangkan } \\
\text { perbuatan-perbuatan yang } \\
\text { luhur mencerminkan sikap } \\
\text { kekeluargaan dan gotong } \\
\text { royong }\end{array}$ \\
\hline
\end{tabular}




\begin{tabular}{|c|c|c|c|c|}
\hline & & $\begin{array}{l}\text { Pelayanan } \\
\text { agama dan } \\
\text { moral }\end{array}$ & $\begin{array}{l}\text { Penanaman nilai- } \\
\text { nilai kesederhanaan } \\
\text { dan kemandirian. } \\
\text { Bahsul masail } \\
\text { bersama tokoh- } \\
\text { tokoh agama dan } \\
\text { masyarakat yang } \\
\text { membahas } \\
\text { permasalahan- } \\
\text { permasalahan yang } \\
\text { ada di dalam } \\
\text { kehidupan } \\
\text { masyarakat } \\
\end{array}$ & $\begin{array}{l}\text { Butir sila-5, tidak hidup } \\
\text { mewah dan boros. } \\
\text { Butir sila- } 4 \text {, musyawarah } \\
\text { untuk mencapai kata } \\
\text { mufakat dengan semangat } \\
\text { kekeluargaan }\end{array}$ \\
\hline & & $\begin{array}{l}\text { Pusat } \\
\text { solidaritas dan } \\
\text { ukhuwah } \\
\text { Isalamiyah } \\
\text { (sosial) }\end{array}$ & \begin{tabular}{lr}
\multicolumn{2}{l}{ Mengadakan } \\
sunatan masal, \\
santunan & anak \\
yatim, r dan \\
sosialisasi & vaksin \\
serta & keluarga \\
berencana. & \\
\end{tabular} & $\begin{array}{l}\text { Butir sila-5, } \\
\text { mengembangkan } \\
\text { perbuatan-perbuatan yang } \\
\text { luhur mencerminkan sikap } \\
\text { kekeluargaan dan gotong } \\
\text { royong }\end{array}$ \\
\hline \multirow{4}{*}{3} & \multirow{4}{*}{$\begin{array}{l}\text { Pesantren } \\
\text { Miftahul } \\
\text { Jannah Rejang } \\
\text { Lebong }\end{array}$} & $\begin{array}{l}\text { Pusat Kajian } \\
\text { Islam } \\
\text { (Pendidikan) }\end{array}$ & $\begin{array}{l}\text { Pendidikan yang } \\
\text { diselenggarakan } \\
\text { seimbang antara } \\
\text { pendidikan agama } \\
\text { dan umum } \\
\end{array}$ & $\begin{array}{l}\text { Butir sila-2, mengakui } \\
\text { persamaan hak dan } \\
\text { kewajiban antar manusia }\end{array}$ \\
\hline & & $\begin{array}{l}\text { Pusat } \\
\text { Pengembangan } \\
\text { dakwah } \\
\text { (tasamuh) }\end{array}$ & $\begin{array}{l}\text { Peringatan hari-hari } \\
\text { besar nasional dan } \\
\text { islam disertai } \\
\text { dengan lomba yang } \\
\text { melibatkan } \\
\text { masyarakat umum } \\
\end{array}$ & $\begin{array}{l}\text { Butir sila-5, } \\
\text { mengembangkan } \\
\text { perbuatan-perbuatan yang } \\
\text { luhur mencerminkan sikap } \\
\text { kekeluargaan dan gotong } \\
\text { royong }\end{array}$ \\
\hline & & $\begin{array}{l}\text { Pelayanan } \\
\text { agama dan } \\
\text { moral }\end{array}$ & $\begin{array}{l}\text { Memberikan } \\
\text { contoh dan suri } \\
\text { tauladan yang baik } \\
\text { terhadap para santri } \\
\text { serta membuka } \\
\text { pengajian umum } \\
\text { yang dilaksanakan } \\
\text { secara rutin setiap } \\
\text { pekan }\end{array}$ & 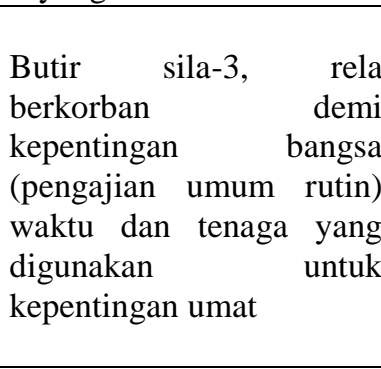 \\
\hline & & $\begin{array}{l}\text { Pusat } \\
\text { solidaritas dan } \\
\text { ukhuwah } \\
\text { Isalamiyah } \\
\text { (social) }\end{array}$ & $\begin{array}{lr}\text { Memberikan } \\
\text { pengobatan gratis, } \\
\text { sosialisasi keluarga } \\
\text { berencana } \\
\text { pengajian akbar } \\
\text { yang } \quad \text { diikuti } \\
\end{array}$ & $\begin{array}{l}\text { Butir sila-5, } \\
\text { mengembangkan } \\
\text { perbuatan-perbuatan yang } \\
\text { luhur mencerminkan sikap } \\
\text { kekeluargaan dan gotong } \\
\text { royong }\end{array}$ \\
\hline
\end{tabular}


Mustofa, Syah: Pesantren sebagai Benteng Ideologi Pancasila| 113

\begin{tabular}{|c|c|c|c|c|}
\hline & & & masyarakat luas & $\begin{array}{l}\text { Butir sila-1, percaya dan } \\
\text { takwa kepada Tuhan yang } \\
\text { Maha Esa berdasarkan } \\
\text { kemanusiaan yang adil } \\
\text { dan beradab }\end{array}$ \\
\hline \multirow{4}{*}{4} & \multirow{4}{*}{$\begin{array}{l}\text { Pesantren } \\
\text { Imam Syafi'I } \\
\text { Rejang } \\
\text { Lebong }\end{array}$} & $\begin{array}{l}\text { Pusat Kajian } \\
\text { Islam } \\
\text { (Pendidikan) }\end{array}$ & $\begin{array}{lr}\text { Fokus } & \text { kepada } \\
\text { tahfid al } & \text { Quran dan } \\
\text { lebih } & \text { tertutup. } \\
\text { Tidak } & \text { ada } \\
\text { pendidikan } & \text { umum } \\
\text { yang lain } & \\
\end{array}$ & $\begin{array}{l}\text { Butir sila-1, tidak } \\
\text { memaksakan agama atau } \\
\text { kepercayaan kepada orang } \\
\text { lain }\end{array}$ \\
\hline & & $\begin{array}{l}\text { Pusat } \\
\text { Pengembangan } \\
\text { dakwah } \\
\text { (tasamuh) }\end{array}$ & $\begin{array}{l}\text { Pengajian hanya } \\
\text { diikuti oleh yang } \\
\text { memiliki } \\
\text { pemahaman yang } \\
\text { sama }\end{array}$ & \\
\hline & & $\begin{array}{l}\text { Pelayanan } \\
\text { agama dan } \\
\text { moral }\end{array}$ & $\begin{array}{l}\text { Memberikan } \\
\text { pemahaman } \\
\text { kewajiban muslim } \\
\text { melalui pengajian } \\
\text { fikih }\end{array}$ & $\begin{array}{l}\text { Butir sila-1, percaya dan } \\
\text { takwa kepada Tuhan yang } \\
\text { Maha Esa }\end{array}$ \\
\hline & & $\begin{array}{l}\text { Pusat } \\
\text { solidaritas dan } \\
\text { ukhuwah } \\
\text { Isalamiyah } \\
\text { (sosial) }\end{array}$ & $\begin{array}{l}\text {---------------- } \\
\text { menjalin kerjasama } \\
\text { dengan wali santri } \\
\text { "polisi/TNI dan } \\
\text { yang lain" tidak } \\
\text { melibatkan } \\
\text { masyarakat umum } \\
\text { atau masyarakat di } \\
\text { sekitar pesantren }\end{array}$ & ---- \\
\hline
\end{tabular}

\section{PENUTUP}

Peran dan fungsi pesantren di kabupaten Rejang Lebong dan Kepahiang dalam membentengi Pancasila sangat baik, terutama pada pesantren Miftahul Janah, Darussalam, dan al Munawarah. Hal itu dapat dilihat dari segi Pendidikan, dakwah yang tasamuh, pelayanan agama dan moral serta menjadi pusat ukhuwah islamiyah (sosial). Namun tidak demikian dengan pesantren Imam as Syafi'I Bandung, warga yang memilih lebih tertutup dan berbeda dengan pesantren pada umumnya. 
Usaha-usaha yang sudah dilakukan oleh pesantren di kabupaten Rejang Lebong dan Kepahiang dalam membentengi ideologi Pancasila terutama di tiga pondok pesantren (Miftahul Jannah, Darussalam, dan al Munawaroh) adalah pembinaan islam yang ramah bersama TNI dan polisi, peringatan hari santri, upacara seminggu sekali dan hari-hari nasional, serta bakti sosial yang diikuti oleh masyarakat luas. Adapun usaha yang dilakukan oleh pesantren Imam as Syafii adalah menjalin komunikasi dengan wali santri yang sepaham dengan mereka dan tidak jarang di antara wali santri tersebut adalah anggota polisi, TNI dan PNS yang aktif.

Dengan demikian, diharapkan ke depan, pesantren-pesantren yang ada bisa meniru usaha pesantren yang sudah berperan dalam membentengi ideologi pancasila, sehingga pesantren tidak lagi dianggap sebelah mata.

\section{DAFTAR PUSTAKA}

Akbar, Husaini Usman dan Purnomo Setiady. Metodologi Penelitian Sosial. Jakarta: PT Bumi Aksara, 2003

Bakry, Noor Ms. Pendidikan Pancasila. Yogyakarta: Pustaka Belajar, 2010

Esha, Muhamad In'am. NU di Tengah Globalisasi; Kritik, Solusi dan Aksi. Malang: UIN Maliki Press, n.d.

Fatiyah. "Pemahaman Santri Mahasiswa Terhadap Nilai-Nilai Pancasila." Adabiyah, 2017

Halim, A. Manajemen Pesantren. Yogyakarta: Pelangi Aksara, 2005

Himawan, Muammar. Pokok-Pokok Organisasi Modern. Jakarta: Bina Ilmu, 2004

Kartodirjo, Sartono. Religious Movement of Java in The 19th and 20th Centuries,. Yogyakarta, 1970

Madjid, Nurcholis, Bilik-bilik Pesantren Sebuah Potret Perjalanan, Jakarta: Paramidina, 1997

Mastuhu, Dinamika Sistem Pndidikan Pesantren, Jakarta: INIS, 1995 
Nazir, Moh. Metode Penelitian. Bogor: Ghalia Indonesia, 2005

Prastiwi, Merlia Indah. "Politisi Pesantren dan Pergeseran Fungsi Pesantren di Madura." KARSA: Jurnal Sosial \& Budaya Keislaman, 2015: 209

Sarwono, Sarlito Wirawan. Teori- Teori Psikologi Sosial. Jakarta: Rajawali Pers, 2015

Siraj, Said Aqil Islam Sumber Inspirasi Budaya Nusantara Menuju Masyarakat Mutamaddin; Urgensi Kajian Islam Nusantara, Jakarta; LTNU

Soekanto, Soerjono. Sosiologi Suatu Pengantar. Jakarta: Rajawali Press, 2002

Sugiyono. Metode Penelitian Pendidikan (Pendekatan Kuantitatif, Kualitatif Dan R\&D) . Bandung: Alfabeta, 2015

Suhardono, Edy. Teori Peran (Konsep, Derivasi dan Implikasinya). Jakarta: Jakarta: PT Gramedia, 1994

Sunoto. Mengenal Filsafat Pancasila: Pendekatan melalui Metafisika, Logika, dan Etika. Yogyakarta: Hanindita, 2003

Sutrisno. "Peran Ideologi Pancasila Dalam Perkembangan Konstitusi Dan Sistem Hukum di Indonesia." JPK: Jurnal Pancasila \& Kewarganegaraan, 2016

Utomo, Bambang Ruseno. Hidup Bersama di Bumi Pancasila, Sebuah Tinjauan Tentang Hubungan Islam dan Kristen di Indonesia. Malang : Pusat Studi Agama dan Kebudayaan, 1993 